\title{
ADULT FATHEAD MINNOW, PIMEPHALES PROMELAS, PARTIAL LIFE-CYCLE REPRODUCTIVE AND GONADAL HISTOPATHOLOGY STUDY WITH BISPHENOL A
}

\author{
Ellen Mihaich, ${ }^{*} \dagger$ Jon Rhodes, $\ddagger$ Jeff Wolf, $§$ Nelly van der Hoeven, $\|$ Daniel Dietrich,\# A. Tilghman Hall, $† \dagger$ \\ Norbert Caspers, $\nmid \dagger$ Lisa Ortego, $\dagger$ Charles Staples, $\S$ Steve Dimond, || || and Steven Hentges\#\# \\ $\dagger \mathrm{ER}^{2}$ for SABIC Innovative Plastics, Durham, North Carolina, USA \\ $\ddagger$ ABC Laboratories, Columbia, Missouri, USA \\ $\S$ Experimental Pathology Laboratories, Sterling, Virginia, USA \\ $\|$ EcoStat, Leiden, The Netherlands \\ \#Environmental Toxicology, University of Konstanz, Germany \\ ††Bayer CropScience, Research Triangle Park, North Carolina, USA \\ $\ddagger \ddagger$ Currenta, Leverkusen, Germany \\ $\S \S$ Assessment Technologies, Keswick, Virginia, USA \\ ||||SABIC Innovative Plastics, Pittsfield, Massachusetts, USA \\ \#\#American Chemistry Council, Washington, DC, USA
}

\begin{abstract}
Bisphenol A (BPA) is an intermediate used to produce epoxy resins and polycarbonate plastics. Although BPA degrades rapidly in the environment with aquatic half-lives from 0.5 to $6 \mathrm{~d}$, it can be found in aquatic systems because of widespread use. To evaluate potential effects from chronic exposure, fathead minnows were exposed for $164 \mathrm{~d}$ to nominal concentrations of $1,16,64$, 160 , and $640 \mu \mathrm{g} / \mathrm{L}$ BPA. Population-level endpoints of survival, growth, and reproduction were assessed with supplemental endpoints (e.g., vitellogenin, gonad histology), including gonad cell type assessment and quantification. No statistically significant changes in growth, gonad weight, gonadosomatic index, or reproduction variables (e.g., number of eggs and spawns, hatchability) were observed; however, there was a significant impact on male survival at $640 \mu \mathrm{g} / \mathrm{L}$. Vitellogenin increased in both sexes at $64 \mu \mathrm{g} / \mathrm{L}$ or higher. Gonad cell type frequencies were significantly different from controls at $160 \mu \mathrm{g} / \mathrm{L}$ or higher in males with a slight decrease in spermatocytes compared with less mature cell types, and at $640 \mu \mathrm{g} / \mathrm{L}$ in females with a slight decrease in early vitellogenic cells compared with less mature cells. The decrease in spermatocytes did not correspond to a decrease in the most mature sex cell type (spermatozoa) and did not impair male fertility, as hatchability was not impacted. Overall, marginal shifts in gametogenic cell maturation were not associated with any statistically significant effects on population-relevant reproductive endpoints (growth, fecundity, and hatchability) at any concentration tested.
\end{abstract}

Keywords-Bisphenol A Fathead minnow Gonad histopathology Endocrine

\section{INTRODUCTION}

Bisphenol A (BPA) is a chemical intermediate used to produce epoxy resins and polycarbonate plastics. Although BPA degrades rapidly in the environment, as demonstrated in both standard biodegradation tests and in environmentally relevant river die-away studies [1,2], exposure to low concentrations of BPA occurs in aquatic systems primarily from discharges into wastewater treatment plants during its manufacturing and use [3,4]. In North America and Europe, median BPA concentrations in fresh surface waters of 0.081 and $0.01 \mu \mathrm{g} / \mathrm{L}$, respectively, have been reported [5].

In recent years, BPA has been the focus of much attention because of its reported weak estrogenic activity. Increased concentrations of the egg-yolk protein vitellogenin (VTG) have been reported in laboratory studies of male fish exposed to BPA $[6,7]$. Other studies in the literature point to increases in VTG, gonadal changes, and skewed sex ratios in fish in the environment as evidence of exposure to hormonally active compounds (see reviews by Vos et al. [8] and Ankley and Giesy [9]), although determining a direct cause-and-effect response from

\footnotetext{
* To whom correspondence may be addressed
} (emihaich@nc.rr.com). field work is difficult. Evaluating the usefulness of this type of information requires an understanding of how the biomarker relates to the overall health of an organism, or more importantly, the population. Although a chemical may interact with and change certain biomarkers, it does not mean that it will cause adverse effects in organisms. In fish studies, biomarkers such as histopathology, sex ratio evaluations, and VTG, to name just a few, can be useful as a first screen to identify potential effects and can thus help to guide the planning and conduct of robust partial/full life-cycle or multigenerational studies that can be used to evaluate population-level responses. Taken together, partial/full life-cycle and multigenerational studies can also prevent false conclusions regarding actual hazards that can occur when only one biomarker is considered in isolation $[10,11]$. That longer-term fish studies encompassing a larger portion of the life cycle can provide data with more certainty in terms of the relevance of results is well accepted. These lifecycle studies provide for exposure of fish during all of the sensitive life stages and furnish adequate data for quantitative risk assessments and population modeling [12]. If biomarkers are also included in the design, a more complete evaluation of potential endocrine modes of action can be achieved.

To understand whether possible hormonally mediated effects could translate into population-level responses, a fathead minnow multigenerational study with BPA was performed in 
2001 to assess standard survival and reproduction endpoints. In parallel, the proportional frequency of testicular cell types such as spermatogonia, spermatocytes, spermatids, spermatozoa, and other cells in testis sections of fish exposed to various concentrations of BPA was analyzed [13-15]. Histopathological endpoints were not originally included as part of the multigenerational test with BPA; consequently, the experimental design was not optimized to evaluate potential gonadal cell effects. Uncertainty as to the robustness of the results of the additional parameters examined in the BPA study [14], due to questions about both the techniques employed in the histological assessment of testicular cell type and the statistical interpretation of testicular cell data, led to the development of a comprehensive testing program designed to assess whether changes in the relative proportions of testicular and ovarian cell types result from chronic exposure to BPA. This detailed testing program first focused on developing optimized techniques for the preparation, preservation, and processing of fathead minnow gonadal tissue, and the creation of manual tagging procedures for the identification and quantification of gonadal cell types [16]. In addition, before the performance of the definitive partial life-cycle study reported here, a methodology demonstration and range-finding study were conducted that included the development of appropriate statistical techniques for evaluation of the data.

The primary objective of this partial life-cycle study was to determine whether changes to the distribution of testicular and ovarian cell types result from exposure for $164 \mathrm{~d}$, the duration of the original Sohoni et al. study [13], to a range of concentrations of BPA $(1,16,64,160$, and $640 \mu \mathrm{g} / \mathrm{L})$. Population-level endpoints of survival, growth, reproduction, and development were assessed, as were the supplemental endpoints of plasma VTG, gonadosomatic index (GSI), and gonad histopathology. Given that the potential endocrine-related effects of BPA exposure on gonadal histopathology and gametogenic cell distribution were evaluated along with fecundity and hatchability, these effects could be interpreted in conjunction with established, internationally accepted and meaningful biological population-level effect endpoints (fecundity and hatchability) [17,18].

\section{MATERIALS AND METHODS}

\section{Test substance}

Bisphenol A (4,4'-isopropylidene diphenol, CAS 80-05-7), an opaque white granular solid, with a purity of $99.76 \%$ was supplied to ABC Laboratories by Research Triangle Institute International.

\section{Test species}

Fathead minnows (Pimephales promelas) were supplied by ABC Laboratories from in-house spawning cultures. The fish used for the present study were approximately $120 \mathrm{~d}$ post hatch (dph) when the test was initiated. During the three-week acclimation period before test initiation, fish were maintained under flow-through conditions in a fiberglass raceway at temperatures ranging between 24 and $27^{\circ} \mathrm{C}$. The fish were fed a standard commercially prepared salmon starter (Rangen) supplemented with live and frozen brine shrimp. No mortalities were recorded, nor was there any evidence of disease during the acclimation period before test initiation.

During the test, adult fish were fed frozen brine shrimp (Artemia; San Francisco Bay Brand) and a commercially prepared salmon starter (Rangen). Larval fish from the hatchability trials were fed live brine shrimp nauplii supplemented with rotifers. Food was provided ad libitum at least twice daily for the adults and once daily for the larval fish. All food for the adults was withheld $24 \mathrm{~h}$ before study termination.

\section{Test method and exposure conditions}

The study was adapted from the U.S. Environmental Protection Agency guidance for a fish full-life-cycle study [19] and was conducted in accordance with Good Laboratory Practice standards [20,21]. An intermittent-flow proportional diluter was used for the introduction of a solution of BPA and control dilution water to each of eight replicate test chambers per treatment. Dilution water, which originated from a deep well on site, was passed through a polypropylene cartridge filter that contained an ultraviolet sterilizer before being delivered to the diluter system. The diluter face and delivery tubes were constructed from glass. Volumetric calibration checks were performed throughout the study to verify the accuracy of the flow-splitting and mixing cells, which divided the dilution water control and each of the five test solutions into eight aliquots before delivering these to the eight test chambers per treatment. The target delivery volume with each diluter cycle was $1.5 \mathrm{~L} /$ replicate, with an average of $493 \mathrm{~L} /$ replicate/d or 11.2 volume additions per $\mathrm{d}$.

The exposure chambers were rectangular glass aquaria that measured $77.6 \mathrm{~cm}$ in length by $21.8 \mathrm{~cm}$ in width by $30.5 \mathrm{~cm}$ in height with an exposure solution depth of $26.0 \mathrm{~cm}$, which yielded an exposure solution volume of $44 \mathrm{~L}$. All exposure chambers were drained through the side of the chamber to a floor drain. When sexually mature adults were paired, each exposure chamber was subdivided by a stainless steel screen into four individual spawning areas to prevent breeding males from fighting. One additional screened area in each chamber was used for temporarily holding extra fish after pairing and for hatchability trials. The exposure chambers were randomly arranged (randomized block design) in single rows in a thermostatically heated exposure system. The exposure chambers were cleaned and siphoned as needed to remove waste material and uneaten food and to minimize excess microbial growth on the bottom and sides of the chambers and on the stainless steel screen.

The exposure system was temperature regulated to maintain a mean temperature of $25 \pm 1^{\circ} \mathrm{C}$ in the aquaria. An electronically controlled photoperiod (16:8 h light:dark) with a simulated dawn and dusk transition period was provided. Light intensity was measured four times during the test (days 9, 111, 141, and 158; for a total of 96 individual measurements) and averaged $824 \pm 92$ lux (577-1,027 lux) at the surface of the exposure chambers during full daylight.

Treatment groups consisted of a dilution water control and nominal BPA concentrations of 1, 16, 64, 160, and $640 \mu \mathrm{g} / \mathrm{L}$. Diluter stock solutions were prepared at a nominal concentration of $1,066 \mu \mathrm{g} / \mathrm{L}$ in 17 - to $18-\mathrm{L}$ volumes by adding an appropriate quantity of BPA to deionized water in an ultrasonic water bath maintained between 40 and $45^{\circ} \mathrm{C}$ and by raising the $\mathrm{pH}$ of the solution with $\mathrm{NaOH}$, followed by continuous stirring of the clear solution until use in the diluter metering system. The stock solution $\mathrm{pH}$ ranged from 10.5 to 12 after preparation. A fresh stock solution was prepared every 1 to $7 \mathrm{~d}$, with a total of 34 stock solutions being prepared during the test.

\section{Exposure initiation}

Exposure solution flow was initiated $13 \mathrm{~d}$ before distribution of fish to the test chambers. The test was initiated over a 4-d 
period, with two of the eight replicates per concentration being randomly selected for initiation each day. On each of the $4 \mathrm{~d}$ (day 0 for those replicates), eight females followed by eight males $(120 \mathrm{dph})$ were impartially selected and added to each replicate. This provided a total of 16 fish per replicate exposure chamber and a total of 128 fish per treatment. During the first $42 \mathrm{~d}$ (prespawn phase), observations of abnormal behavior, physical abnormalities, and mortality were made daily by visual inspection of each test chamber. Dead fish, when present, were removed and discarded. Eggs spawned during this period were removed and discarded.

On day 42 of the exposure, all fish were carefully netted from the exposure chambers and transferred to individual 1-L beakers that contained the test solution. Sex was determined by visually assessing morphological characteristics such as tubercle formation on the heads of males, body shape, and size. One male and one female were transferred back into each of the partitioned spawning areas. This provided four spawning pairs per replicate and 32 spawning pairs per treatment (BPA concentrations and the control group). Up to three of the remaining males and females per treatment group were transferred to the hatchability trial area in the exposure chamber to provide potential replacements for spawning pairs that died or did not exhibit full sexual development during the early part of the spawning phase of the test. As with test initiation, pairing was staggered over a 4-d period, with two of the eight replicates being selected for pairing each day in the order in which they were initiated. Fish not used during the spawning phase were euthanized with tricaine methanesulfonate $(>1,000 \mathrm{mg} / \mathrm{L})$ and discarded

After pairing, an egg-laying substrate in the form of a U-shaped stainless steel tile was placed in each partitioned area of the exposure chamber that contained a spawning pair. During the next $122 \mathrm{~d}$ (spawning phase), observations of abnormal behavior, physical abnormalities, mortality, and spawning activity were made daily by visual inspection of each exposure chamber and spawning substrate. Dead fish, when present, were removed and discarded. If mortality was observed over the first $14 \mathrm{~d}$ of the spawning phase, dead fish were replaced with extra males or females from the hatchability area. Pairs in which no spawning was observed during this 14-d period were also replaced. Once the spawning phase was established, the residual spawning pair replacements were removed from the exposure chambers and euthanized to provide space for egg hatchability trials. All eggs spawned during the spawning phase were removed from the spawning substrates and counted. Eggs not used for hatchability trials were discarded.

\section{Physical and chemical parameters}

Chemical and physical parameters of exposure solution temperature, dissolved oxygen concentration, $\mathrm{pH}$, alkalinity, hardness, and conductivity were measured at study initiation, study termination, and weekly throughout the exposure. Exposure solution $\mathrm{pH}$, conductivity, hardness, and alkalinity were measured on a weekly basis in one of eight replicate aquaria in the control and low and high BPA treatments. Exposure solution temperature and dissolved oxygen were measured at least weekly in four of the eight replicate aquaria (two replicates at termination) of the control and each BPA treatment. Aquaria that were measured for these endpoints were alternated on each sample day. The temperature of a centrally located exposure chamber in the exposure system was continuously monitored by an electronic data logger.

\section{Analytical methods}

Analytical confirmation of the exposure solution BPA concentrations was performed by high-performance liquid chromatography (Agilent Technologies) with ultraviolet fluorescence detection (excitation wavelength $=230 \mathrm{~nm}$; emission wavelength $=308 \mathrm{~nm}$ ). Separations were achieved on a Zorbax Eclipse XDB C8 column $(150 \mathrm{~mm} \times 4.6 \mathrm{~mm})$, with a mobile phase of 65:35 methanol: reagent water, a flow rate of $1 \mathrm{ml} / \mathrm{min}$, and an injection volume of $900 \mu \mathrm{l}$. The limit of quantitation was $0.293 \mu \mathrm{g} / \mathrm{L}$

To confirm exposure system equilibration, test solution samples were collected before test initiation, again on days 0 and 3, and at least weekly thereafter. Bisphenol A concentrations were measured in a single composite test solution sample of all replicates within each treatment. Samples were collected subsurface from the approximate center of each test chamber and composited. On each scheduled sample day, a diluter stock solution sample and BPA-fortified quality control samples were prepared and analyzed concurrently with test solution samples.

\section{Hatchability trials}

Egg hatchability trials were carried out at two time points during the 164-d exposure: mid-phase (between days 85 and 105) and late phase (between days 135 and 155). During each 20-d hatchability period, eggs were collected from one or more of the spawning pairs in each treatment. For each time-point, 50 eggs were collected from at least three separate spawning pairs from separate replicate chambers within a treatment group. Eggs were removed from the spawning substrates and transferred to egg incubation cups constructed from glass jars with a Nitex screen that replaced the bottom. The incubation cups were oscillated vertically in the test chamber. For each set of eggs collected, the eggs and larvae were observed for hatching, mortality, and developmental abnormalities for $6 \mathrm{~d}$ postfertilization.

\section{Necropsy and histopathology procedures}

At termination, all surviving parental generation fish were anesthetized using tricaine methanesulfonate $(125-150 \mathrm{mg} / \mathrm{L})$, and measurements were obtained of standard length (measured from the mouth to the caudal peduncle) and blotted wet weight. After weighing, the caudal peduncle was severed, and blood was collected from the caudal artery with a heparinized microhematocrit capillary tube. Anesthetized fish were then euthanized humanely via a transverse blade cut through the cervical spinal cord. The capillary tubes were placed on ice until centrifugation at approximately $3,200 \mathrm{~g}$ for $5 \mathrm{~min}$. Plasma samples were transferred to centrifuge tubes containing 0.13 units of lyophilized aprotinin, and tubes were placed on dry ice before being transferred to a $-80^{\circ} \mathrm{C}$ cryogenic freezer for subsequent analysis of VTG.

For each fathead minnow, left and right gonads were collected and weighed individually following methods described in Wolf et al. [16]. Testes were fixed and maintained in 5\% glutaraldehyde. Ovaries and the remaining carcasses of the male and female fish were fixed in Bouin's solution for at least $18 \mathrm{~h}$, rinsed in $70 \%$ ethanol, and maintained in $10 \%$ neutral buffered formalin. The left and right ovaries, as well as tissues containing grossly evident lesions from male and female fish, were trimmed as needed for optimal embedding, embedded in paraffin, and processed to block according to standard histological procedures. The ovary tissue blocks were trimmed to their 
largest cross-sectional area, microtomed to approximately 4 to $5 \mu \mathrm{m}$ thickness, mounted on glass slides, stained with hematoxylin and eosin, and coverslipped. Tissues containing grossly evident lesions were trimmed to best illustrate the lesion and processed to slides. The left and right testes were embedded in glycol methacrylate and processed to block. Testis pairs were trimmed to their largest longitudinal sectional area, microtomed to 1 to $2 \mu \mathrm{m}$ thickness, mounted on grid slides (glass slides that have $8 \times 8$ preprinted grids on their undersides), stained with hematoxylin and eosin, and coverslipped. For both sexes, each gonad (left or right) was embedded in a separate block.

As part of the histological assessment, slides were examined microscopically for morphological abnormalities. The severity of any inflammatory, degenerative, or proliferative change was graded from 1 to 5 according to the following system: $1=$ minimal, $2=$ slight $/$ mild, $3=$ moderate, $4=$ moderately severe, and $5=$ severe/high. Grossly observed changes were correlated with microscopic diagnoses whenever possible. The image analysis procedures were based on the methodology and equipment described in Wolf et al. [16].

Using the $40 \times$ objective, four digital images (each $0.22 \mathrm{~mm} \times 0.29 \mathrm{~mm}$ subject area) were obtained as uncompressed TIFF files from each of the left and right testis sections as available (i.e., eight images total per male fish). To ensure the acquisition of non-overlapping testis images, areas for photography were selected from the centers of grid squares that were chosen impartially, although testis areas with obvious collection or processing artifacts were avoided. For each digital image, the ImagePro Plus application (Media Cybernetics, version 5.1.0.20) was used to manually tag individual testis cells to cell type. A virtual grid consisting of $400(20 \times 20)$ individual grid intersection points (GIP) was applied to each image as an overlay. The computer mouse was used to manually tag each of the 400 GIP per image with one of 10 different colored dots, according to the cell type or object of interest that was spatially associated with the GIP: spermatogonium, spermatocyte, spermatid, spermatozoa, vacuolated cell (VC), apoptotic body cell $(\mathrm{ABC})$, interstitial (Leydig) cell, Sertoli cell, interstitial tissue or unknown cell type (ITUC), or empty space. Counts per image of the different testicular cell types were tabulated as a summation of the counts per testis (left or right). A total of 1,600 GIP, including ITUC and empty spaces, were counted per left and right testis, thus providing 3,200 GIP for each male fish.

Using the $4 \times$ objective, two digital photomicrographic images were obtained from each of the left and right ovary sections as available (i.e., four images total per female fish). To ensure the acquisition of non-overlapping ovary images, an ultrafine permanent marker was used to draw a line on the glass slide to approximately bisect each ovary section perpendicular to its long axis. The two areas for photography were selected impartially from each half of the ovary. Using the ImagePro Plus application and the computer mouse, each ovarian follicle (all follicles were counted) was sequentially tagged with one of six different solid-colored squares that represented one of the following follicle cell types: perinucleolar, cortical alveolar, early vitellogenic, late vitellogenic, mature/spawning, and atretic. An average (arithmetic mean) of 408.5 follicles per ovary was counted from the four images of ovary per female fish. Counts per image of the different follicle types were tabulated as summed counts per ovary (left or right).

\section{Plasma VTG analysis}

Adult fathead minnow plasma VTG levels were measured using a Biosense Laboratories AS enzyme-linked immunosorb- ent assay kit (Carp Vitellogenin ELISA Kit product number V01003402) supplied by Cayman Chemical. The wells of the microtiter plates were precoated with a specific capture antibody that binds to VTG in standards or samples added to the wells. A different VTG-specific detecting antibody was added to create a sandwich of VTG and the antibody, which was detected with an enzyme-labeled secondary antibody. The enzyme activity was determined by adding a substrate that produced a colored product in which the color intensity was directly proportional to the amount of VTG present. The absorbance was read at a wavelength of $492 \mathrm{~nm}$.

\section{Statistical analysis}

Effects of BPA were assessed on 37 and 27 variables in males and females, respectively. In addition, five different variables were investigated for each breeding pair. For most variables, several statistical tests were used to assess whether a significant effect was observed. Depending on the type of variable, these tests were: (1) parametric (Dunnett) or nonparametric (Wilcoxon or Jonckheere-Terpstra); (2) using, if possible, the replicate aquaria mean, otherwise data from individual fish (data per partitioned spawning area) as the observation; or (3) performing either a variable-wise comparison between each treatment and the control (Dunnett or Wilcoxon), or a trend test across treatments (Jonckheere-Terpstra). For each of the variables, the observed effect was tested at the 5\% significance level. Using a 5\% significance level means that on average 1 of 20 comparisons will lead, by chance, to a statistically significant effect on the compared variable. A simultaneous significance test was used to guard against this increase in the probability of making a type 1 error of incorrectly concluding a significant effect. Thus, the significance level of 5\% was distributed equally among five groups of related variables: (1) size variables (standard length, wet wt, gonad wt, GSI), (2) reproduction variables (number of eggs per surviving pair, number of spawns per surviving pair, mean number of eggs per spawn, day of first spawn, hatchability of eggs), (3) histopathological tissue score variables (for males, 23 lesion types identified, and for females, 16), (4) cell frequency variables (relative frequency for eight male and five female cell types), and (5) a remnant group encompassing survival data and VTG levels. Subsequently, the simultaneous significance level within each group was then split over the variables observed in that group, leading to $\alpha=0.0017$ for size variables, $\alpha=0.0020$ for reproduction variables, and $\alpha=0.0026$ for survival and VTG. For the histopathological lesion scores, the $\alpha$ values for male and female tissues were 0.00022 and 0.00032 , respectively. For the cell frequency variables, the significance level $\alpha$ was 0.0013 for the male sperm cell frequencies, 0.026 for the other male gonad cell frequencies, and 0.001 for the female gonad cell frequencies. Effects were considered to be statistically significant only when both the variable-wise and the simultaneous test were significant. If the different tests (parametric or nonparametric) led to different $p$ values, the smallest of the two $p$ values was used. The minimum significant difference (MSD) for simultaneous significant effects using the Dunnett test was also calculated when the Dunnett test was applied.

For the gonadal cell type assessment, data were analyzed for gametogenic cell counts obtained via image analysis of gonad photomicrographs. Spermatogenic cell types counted in the right and left testes included spermatogonia, spermatocytes, spermatids, and spermatozoa. Folliculogenic cell types counted in the right and left ovaries included perinucleolar, cortical alveolar, early vitellogenic, late vitellogenic, mature/spawning, 
and atretic. Logits of the relative cell frequencies were used for the statistical analysis; absolute frequencies could not be used because they are dependent on each other. If one of the absolute frequencies increases, the sum of the others has to decrease. Thus, for both males and females, the logits of the frequency of the most mature cell type in the class of all equally and less mature cell types were calculated. This led to three logit values for each testis and five logit values for each ovary. In the testis, nongerminal cell types were considered to be Leydig cells, ITUC, Sertoli cells, ABC, and VC. Empty spaces were also counted if they occurred at grid intersection points. Per testis, the logit of the frequency of germ cells within all cells (germ and nongerm) and the logits of the frequency of (groups of) nongerm cells within nested groups of the nongerm cells were calculated. This led to another five logit values for the testis. The mean logit per fish was calculated and analyzed statistically. For the cell frequencies, the MSD based on the logit was translated to a range at which the frequencies could be significantly different from the control values.

\section{RESULTS}

\section{Analytical measurements}

Mean measured concentrations of the BPA test solution ranged from 81 to $119 \%$ of nominal and established the geometric time-weighted mean measured concentrations of less than 0.29 (control), 1.19, 13.4, 52.8, 130, and $567 \mu \mathrm{g} / \mathrm{L}$. Given that concentrations remained within $20 \%$ of the nominal concentrations during the 164-d study, the results are expressed relative to the nominal concentration [22].

\section{Water quality}

Mean dissolved oxygen concentrations ranged from 6.5 to $6.6 \mathrm{mg} / \mathrm{L}$, representing 82 to $84 \%$ of saturation at $25^{\circ} \mathrm{C}$. Continuous temperature monitoring in the aquaria indicated that the temperature range was $25 \pm 1{ }^{\circ} \mathrm{C}$ during the entire study. Test solution $\mathrm{pH}$ ranged from 7.75 to 8.08 . Conductivity ranged from 310 to $330 \mu \mathrm{S}$, and hardness and alkalinity (as $\mathrm{CaCO}_{3}$ ) ranged from 136 to $152 \mathrm{mg} / \mathrm{L}$ and 142 to $166 \mathrm{mg} / \mathrm{L}$, respectively.

\section{Survival, growth, and development}

A statistically significant reduction in percent survival was observed for males in the highest treatment group $(640 \mu \mathrm{g} / \mathrm{L})$ only (Table 1). The GSI was derived as the ratio of gonad wet weight to total wet weight, expressed as a percentage. No statistically significant differences in mean standard length, total wet weight, or GSI were observed during the present study (Table 1).

\section{Reproductive parameters}

Five variables were chosen to assess the effects of BPA on fecundity. These included the total number of spawns per surviving breeding pair, the total number of eggs per surviving breeding pair, the mean number of eggs per spawn of the breeding pairs producing at least one spawn, the day of first spawn, and the hatchability of eggs.

Bisphenol A $(\leq 640 \mu \mathrm{g} / \mathrm{L})$ had no statistically significant effects on any of the reproduction variables (number of eggs per surviving breeding pair, number of spawns per surviving breeding pair, mean number of eggs per spawn, and day of first spawning; Table 2). Using individual breeding pairs as observational units, the effects on the number of spawns and the day of first spawning were variable-wise significant at $640 \mu \mathrm{g} / \mathrm{L}$ ( $p=0.019$ for both). These effects were not significant using the vessel mean as the experimental unit, neither were they simultaneously significant. Therefore, these effects are not considered statistically significant (see Statistical Analysis section).

Overall, percent hatch ranged from 0 to $100 \%$ during the mid-phase trial and from 74 to $100 \%$ during the late-phase trial. The mean percent hatch for the mid-phase trial was $89.9 \%$, whereas the late-phase trial mean percent hatch was $97.1 \%$. Three groups of eggs collected from one pair each in the control, in 160 and $640 \mu \mathrm{g} / \mathrm{L}$, during the mid-phase trial exhibited no hatching. Combining both hatching experiments, the effect of the treatment was investigated. Bisphenol A $(\leq 640 \mu \mathrm{g} / \mathrm{L})$ had no statistically significant effects on the hatchability of eggs (Table 2). Using individual breeding pairs as observational units, the effect on the day of first spawning was variable-wise significant at $640 \mu \mathrm{g} / \mathrm{L}$. Despite the latter finding and in view of lacking simultaneous significance, none of the BPA treatments showed a statistically significant reduction in hatch when compared with the control.

\section{Plasma VTG}

Plasma VTG concentrations in male and female fathead minnows are presented in Figure 1. A statistically significant

Table 1. Summary of survival and growth (length, wet wt, gonad wt, and gonado-somatic index) (mean \pm SD) in fathead minnows (Pimephales promelas) exposed to bisphenol A (BPA) for $164 \mathrm{~d}$

\begin{tabular}{|c|c|c|c|c|c|c|c|c|}
\hline & & \multicolumn{7}{|c|}{ Nominal BPA $(\mu \mathrm{g} / \mathrm{L})$} \\
\hline & & 0 & 1 & 16 & 64 & 160 & 640 & $\operatorname{MSD}^{\mathrm{a}}$ \\
\hline \multirow[t]{2}{*}{ Mean $\%$ Survival $^{\mathrm{b}}$} & Male & 91 & 94 & 97 & 88 & 94 & $56^{\mathrm{c}}$ & \\
\hline & Female & 77 & 77 & 69 & 80 & 90 & 94 & \\
\hline \multirow[t]{2}{*}{ Mean Standard Length mm $( \pm \mathrm{SD})$} & Male & $60.1(4.00)$ & $59.6(0.93)$ & $58.5(2.04)$ & $61.3(2.33)$ & $61.0(2.91)$ & $59.5(3.03)$ & $6.3 \%$ \\
\hline & Female & $50.6(2.24)$ & $51.1(1.64)$ & $51.0(2.29)$ & $49.3(2.05)$ & $51.4(1.34)$ & $53.2(1.99)$ & $6.6 \%$ \\
\hline \multirow[t]{2}{*}{ Mean wet weight $g( \pm$ SD) } & Male & $7.20(1.05)$ & $6.89(0.40)$ & $6.49(0.44)$ & $7.21(0.64)$ & $7.18(0.87)$ & $6.07(0.64)$ & $15 \%$ \\
\hline & Female & $3.53(0.57)$ & $3.62(0.61)$ & $3.73(0.58)$ & $3.37(0.54)$ & $3.47(0.40)$ & $3.91(0.54)$ & $26 \%$ \\
\hline \multirow{2}{*}{ Mean gonad weight $g( \pm S D)$} & Male & $0.125(0.028)$ & $0.135(0.019)$ & $0.135(0.029)$ & $0.150(0.031)$ & $0.152(0.028)$ & $0.108(0.023)$ & $40 \%$ \\
\hline & Female & $0.622(0.272)$ & $0.578(0.289)$ & $0.499(0.174)$ & $0.519(0.208)$ & $0.525(0.096)$ & $0.489(0.164)$ & $53 \%$ \\
\hline \multirow[t]{2}{*}{ Mean GSI \% $( \pm \mathrm{SD})$} & Male & $1.73(0.24)$ & $1.95(0.21)$ & $2.06(0.37)$ & $2.12(0.38)$ & $2.13(0.30)$ & $1.75(0.19)$ & $34 \%$ \\
\hline & Female & $16.7(5.2)$ & $15.4(4.8)$ & $13.5(4.7)$ & $14.8(3.6)$ & $14.6(2.0)$ & $11.8(3.0)$ & $35 \%$ \\
\hline
\end{tabular}

${ }^{\text {a }}$ The minimum significant difference (MSD) is given based on the compartment as the experimental unit.

${ }^{\mathrm{b}}$ A nonparametric (trend) test was performed because of lack of normality and homogeneity of variance. For this nonparametric test, an SD was not appropriate.

${ }^{\mathrm{c}}$ Significant differences $(p \leq 0.05)$ from the control.

$\mathrm{GSI}=$ gonadosomatic index. 
Table 2. Reproductive activity exhibited by fathead minnows (Pimephales promelas) during a partial life-cycle exposure to bisphenol A (mean \pm SD) ${ }^{\text {a }}$

\begin{tabular}{|c|c|c|c|c|c|}
\hline $\begin{array}{l}\text { Nominal BPA } \\
\text { concentration }(\mu \mathrm{g} / \mathrm{L})\end{array}$ & $\begin{array}{l}\text { Mean number } \\
\text { of spawns }\end{array}$ & $\begin{array}{l}\text { Total number } \\
\text { of eggs }\end{array}$ & $\begin{array}{l}\text { Mean number } \\
\text { of eggs/spawn }\end{array}$ & $\begin{array}{l}\text { Range of days } \\
\text { to first spawn }\end{array}$ & $\begin{array}{l}\text { Mean percent } \\
\text { egg hatch }\end{array}$ \\
\hline Control & $25.9 \pm 8.4$ & $3,966 \pm 1,907$ & $173 \pm 38$ & $43-58$ & 90 \\
\hline 1.0 & $29.9 \pm 7.8$ & $4,297 \pm 2,519$ & $133 \pm 28$ & $43-49$ & 94 \\
\hline 16 & $27.4 \pm 6.7$ & $5,335 \pm 2,678$ & $181 \pm 27$ & $43-58$ & 96 \\
\hline 64 & $29.1 \pm 5.2$ & $5,208 \pm 1,262$ & $165 \pm 43$ & $43-48$ & 97 \\
\hline 160 & $24.8 \pm 6.6$ & $5,549 \pm 1,661$ & $216 \pm 59$ & $43-61$ & 92 \\
\hline 640 & $19.7 \pm 4.8$ & $3,761 \pm 2,004$ & $166 \pm 45$ & $43-68$ & 89 \\
\hline MSD & $38 \%$ & $71 \%$ & $47 \%$ & $1 \mathrm{~d}$ & $5.9 \%$ \\
\hline
\end{tabular}

${ }^{\mathrm{d}}$ Mean number of spawns and total number of eggs are per breeding pair for the length of the study. No statistically significant effects were noted on any reproductive parameter. The MSD is given based on the compartment as experimental unit.

$\mathrm{BPA}=$ bisphenol $\mathrm{A} ; \mathrm{MSD}=$ minimum significant difference.

increase in VTG in males and females was determined at concentrations of 64,160 , and $640 \mu \mathrm{g} / \mathrm{L}(p<0.0001$ for all three). The plasma VTG increase in male and female fish followed a concentration-response relationship, with the highest concentrations observed in the $640 \mu \mathrm{g} / \mathrm{L}$ treatment. The highest concentration with no simultaneously significant increase in VTG compared with controls in either male or female fish was $16 \mu \mathrm{g} / \mathrm{L}$ ( $p=0.040$ and 0.026 , respectively).

\section{Necropsy and histopathology}

At necropsy, the only findings that were substantially higher in BPA-treated fish than in controls occurred in male fish, and these were small or translucent testes and enlarged kidneys. These effects were evident grossly at the $640 \mu \mathrm{g} / \mathrm{L}$ concentration level (testis) and 160 and $640 \mu \mathrm{g} / \mathrm{L}$ concentration levels (kidney). Small or translucent testes were most often associated with one of several different microscopic diagnoses (germinal epithelium atrophy, hypospermia, failure to recover the testis section), none of which was statistically significant when evaluated independently. Histopathologically, enlarged kidneys exhibited a variety of changes such as dilation of Bowman's spaces, glomerular epithelial cell hyperplasia, hyaline droplets in glomeruli, glomerular mesangial membrane thickening, intravascular proteinaceous fluid, and tubular dilation. Because kidneys were only sampled from the subset of macroscopically affected fish, these findings were not subjected to statistical analysis.

The lesion incidence and severity data were analyzed by the simultaneous nonparametric Jonckheere-Terpstra trend test and redundancy analysis [23], treating each fish as a separate observation. Redundancy analysis was performed to assess the relationship between BPA concentration and the complete set of histopathological gonadal lesion scores, by calculating the percentage of the variance of a given lesion that can be explained by the influence of BPA. Of the 39 different lesions identified, statistically significant increases $(p<0.0001)$ were found only at 640 and $160 \mu \mathrm{g} / \mathrm{L}$ for intravascular proteinaceous fluid in males and at $640 \mu \mathrm{g} / \mathrm{L}$ for intravascular and interstitial proteinaceous fluid in females. Combining all lesion scores in a redundancy analysis showed that no significant effects on the lesions occurred at $64 \mu \mathrm{g} / \mathrm{L}(p=0.11)$ in males and at $160 \mu \mathrm{g} / \mathrm{L}$ $(p=0.30)$ in females. According to this analysis, intravascular (and interstitial in females) proteinaceous fluid was responsible for $65.3 \%$ of the variance attributable to BPA exposure in the males and $32.7 \%$ in the females. The next highest finding in males, mineralization of spermatic ducts, and in females, ovarian cysts, was only responsible for 7.8 and $7.1 \%$ of the variance, respectively. Intravascular (and interstitial in females) proteinaceous fluid was characterized by the presence of unusually dense, homogenous, pink material within blood vessels that were often variably dilated (Fig. 2).

\section{Gonadal cell-type assessment}

Gonad cell-type frequencies are considered to be a highly individual property of the fish, which was supported by the small, if any, vessel effect noted on these. Therefore, to increase the power of the test, the cell-type frequencies were tested using the individual fish as the experimental unit. For testis germ cells, significant differences were observed between the control and the $640 \mu \mathrm{g} / \mathrm{L}$ concentration group for the logits of the relative frequency of spermatids and spermatocytes, each within its group of equally and less mature cell types $(p=0.000017$ and

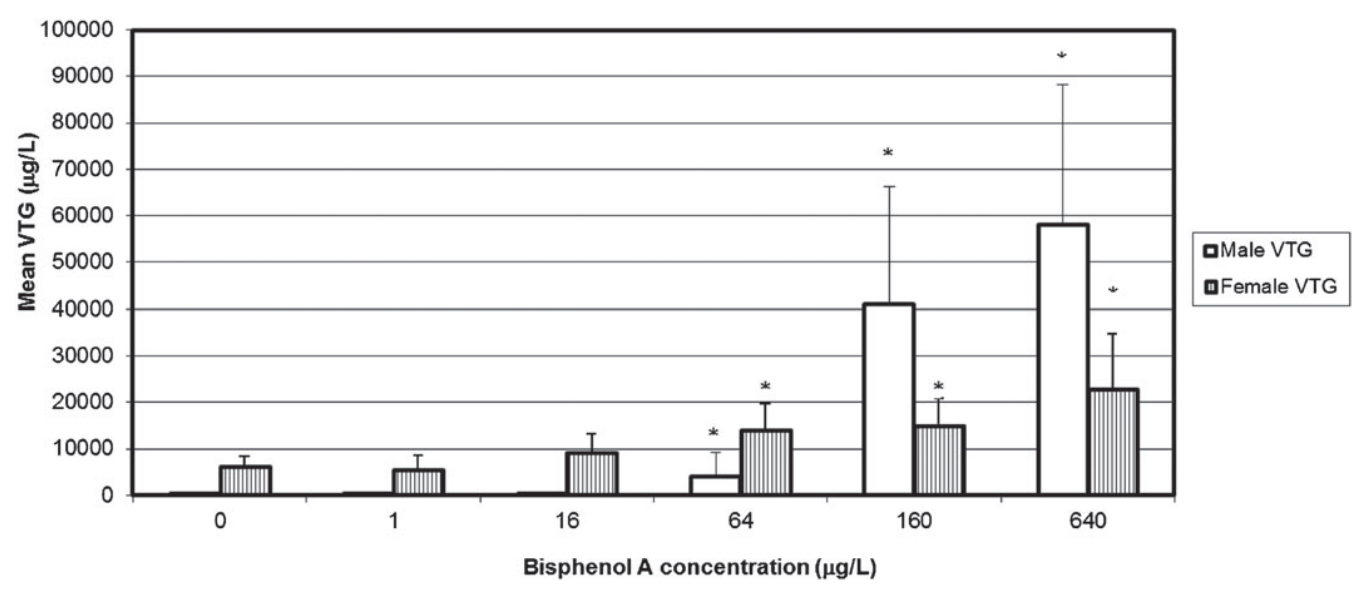

Fig. 1. Plasma vitellogenin concentrations ( $\mu \mathrm{g} / \mathrm{L})$ for male and female fish exposed for $164 \mathrm{~d}$ to bisphenol A. Asterisk (*) indicates significant difference from controls $(0 \mu \mathrm{g} / \mathrm{L}$ treatment $)$ by sex. 
A
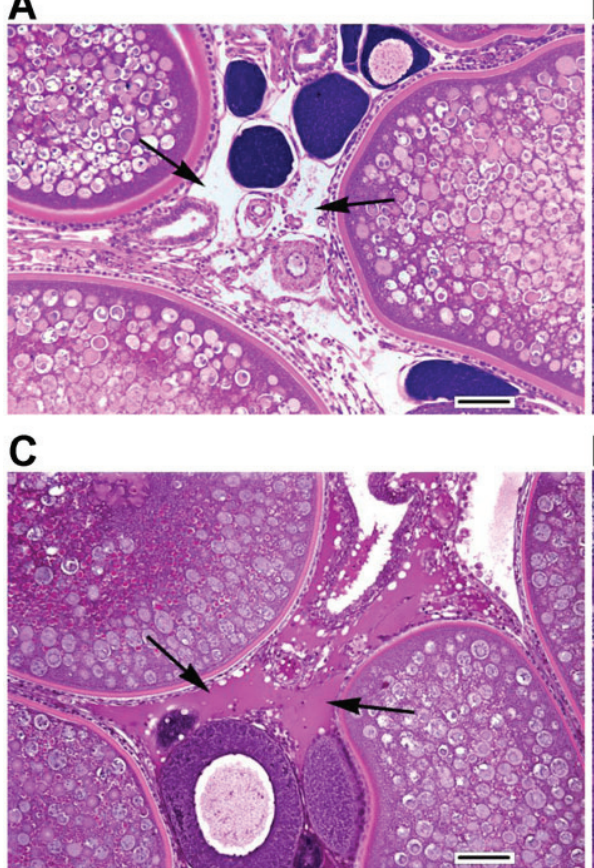

B

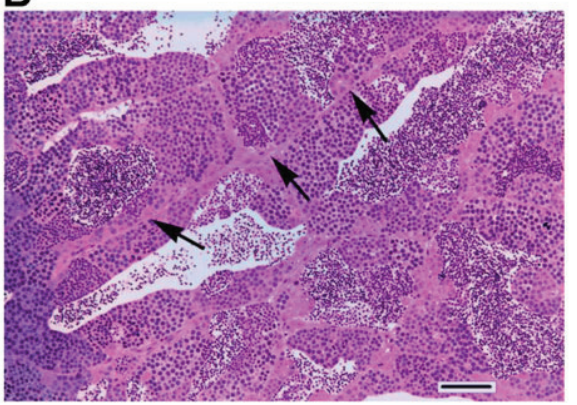

D

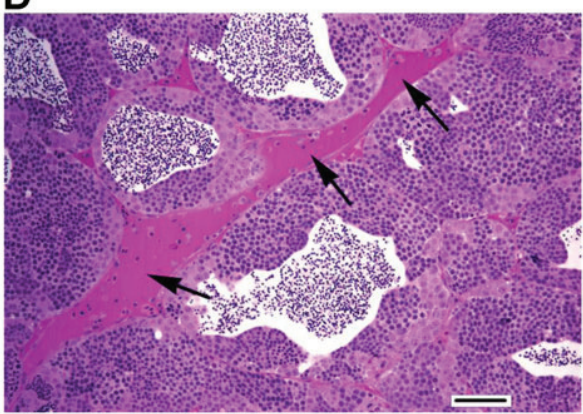

Fig. 2. (A) and (B) Ovary and testis from control fathead minnow, respectively. No proteinaceous fluid in the interstitial space or intravascularly is noted (arrows); (C) Ovary from a $640 \mu \mathrm{g} / \mathrm{L}$ bisphenol A (BPA) female. Proteinaceous fluid is present in the interstitial space (arrow). (D) Testis from a $640 \mu \mathrm{g} / \mathrm{L}$ BPA male. Intravascular proteinaceous fluid is present (arrow). The slight shadow on the left side of each testis image is cast by the presence of the overlying grid slide. $\mathrm{Bar}=50 \mu \mathrm{m}$ for all photomicrographs.

0.0012, respectively; Table 3). Using a trend test, there was also a significant difference in the relative frequency of spermatocytes $(p=0.0010)$ within the group of equally and less mature cell types at $160 \mu \mathrm{g} / \mathrm{L}$. In other words, the frequency of spermatids and spermatocytes relative to spermatogonia and spermatozoa was decreased as compared with controls at $640 \mu \mathrm{g} / \mathrm{L}$, but only the frequency of spermatocytes in relation to the other three cell types was decreased at $160 \mu \mathrm{g} / \mathrm{L}$ (Table 3, Fig. 3). No significant effects were observed on the relative frequency of spermatozoa within the group of equally and less mature cell types.

For the testicular nongerm cells, no simultaneously statistically significant effects (Dunnett test) were observed on the logits of the relative frequency of germ cells within all cells

Table 3. Percentage of median cell frequency (and upper and lower $10^{\text {th }}$ percentile) for the male gonad cell types, including the nonreproductive vacuolated cells (VC), apoptotic body cells (ABC), Sertoli cells, Leydig cells, and interstitial tissue or unknown cells (ITUC), and the mean of the inverse logit of frequencies of these cells within given groups of cell types

\begin{tabular}{|c|c|c|c|c|c|c|c|c|}
\hline & $\begin{array}{l}\text { Nominal BPA } \\
\text { treatments }(\mu \mathrm{g} / \mathrm{L})\end{array}$ & Control & 1 & 16 & 64 & 160 & 640 & $\begin{array}{l}\text { Significantly different } \\
\text { from control if... }\end{array}$ \\
\hline Cell type & $\begin{array}{c}\text { Frequency within the group } \\
\text { of this cell type and... }\end{array}$ & & & & & & & \\
\hline $\begin{array}{l}\text { Reproductive } \\
\text { cells }\end{array}$ & All other cell types in tissue & $\begin{array}{c}93 \%(56 / 95) \\
83 \%^{\mathrm{a}}\end{array}$ & $\begin{array}{c}93 \%(83 / 95) \\
92 \%^{\mathrm{a}}\end{array}$ & $\begin{array}{c}93 \%(86 / 95) \\
93 \%^{\mathrm{a}}\end{array}$ & $\begin{array}{c}94 \%(89 / 97) \\
90 \%{ }^{\mathrm{a}}\end{array}$ & $\begin{array}{c}94 \%(89 / 96) \\
88 \%^{\mathrm{a}}\end{array}$ & $\begin{array}{c}93 \%(87 / 94) \\
91 \%^{\mathrm{a}}\end{array}$ & $<34 \%$ or $>98 \%{ }^{\mathrm{a}}$ \\
\hline Spermatozoa & $\begin{array}{c}\text { Other reproductive cells } \\
\text { Less mature reproductive cells }\end{array}$ & $\begin{array}{c}39 \%(11 / 53) \\
33 \%^{\mathrm{a}}\end{array}$ & $\begin{array}{c}38 \%(21 / 56) \\
37 \%^{\mathrm{a}}\end{array}$ & $\begin{array}{c}46 \%(21 / 59) \\
42 \%{ }^{\mathrm{a}}\end{array}$ & $\begin{array}{c}44 \%(25 / 56) \\
42 \%{ }^{\mathrm{a}}\end{array}$ & $\begin{array}{c}53 \%(32 / 66) \\
49 \%^{\mathrm{a}}\end{array}$ & $\begin{array}{c}37 \%(17 / 59) \\
33 \% \%^{\mathrm{a}}\end{array}$ & $<15 \%^{\mathrm{a}}$ \\
\hline Spermatids & $\begin{array}{c}\text { Other reproductive cells } \\
\text { Less mature reproductive cells }\end{array}$ & $\begin{array}{c}13 \%(7.6 / 15) \\
17 \%^{\mathrm{a}}\end{array}$ & $\begin{array}{c}11 \%(7 / 15) \\
17 \%^{\mathrm{a}}\end{array}$ & $\begin{array}{c}11 \%(5.6 / 15) \\
17 \%^{\mathrm{a}}\end{array}$ & $\begin{array}{c}11 \%(6.6 / 14) \\
17 \%^{\mathrm{a}}\end{array}$ & $\begin{array}{c}8.9 \%(1.4 / 16) \\
13 \%^{\mathrm{a}}\end{array}$ & $\begin{array}{c}8.0 \%(0.1 / 15) \\
7 \% \%^{\mathrm{a}, \mathrm{b}}\end{array}$ & $<7 \%^{\mathrm{a}}$ \\
\hline Spermatocytes & $\begin{array}{l}\text { Other reproductive cells } \\
\text { Less mature reproductive cells }\end{array}$ & $\begin{array}{c}40 \%(32 / 55) \\
82 \%^{\mathrm{a}}\end{array}$ & $\begin{array}{c}41 \%(29 / 57) \\
83 \%^{\mathrm{a}}\end{array}$ & $\begin{array}{c}35 \%(25 / 50) \\
80 \%\end{array}$ & $\begin{array}{c}35 \%(24 / 52) \\
81 \%^{\mathrm{a}}\end{array}$ & $\begin{array}{c}29 \%(18 / 46) \\
75 \% \text {, b,c }\end{array}$ & $\begin{array}{c}30 \%(13 / 48) \\
67 \%^{\mathrm{a}, \mathrm{b}}\end{array}$ & $<70 \%^{\mathrm{a}}$ \\
\hline $\begin{array}{l}\text { Spermatogonia } \\
\text { ITUC }\end{array}$ & $\begin{array}{l}\text { Other reproductive cells } \\
\text { Other nonreproductive cells }\end{array}$ & $\begin{array}{l}7.8 \%(6 / 12) \\
65 \%(56 / 73)\end{array}$ & $\begin{array}{l}7.6 \%(5.8 / 13) \\
71 \%(55 / 80)\end{array}$ & $\begin{array}{l}8.0 \%(5.8 / 12) \\
70 \%(53 / 77)\end{array}$ & $\begin{array}{l}7.3 \%(5.7 / 11) \\
66 \%(50 / 77)\end{array}$ & $\begin{array}{l}7.8 \%(5.8 / 22) \\
69 \%(55 / 77)\end{array}$ & $\begin{array}{l}13 \%(8.2 / 47) \\
66 \%(54 / 74)\end{array}$ & \\
\hline Leydig + ITUC & Nonreproductive cells & $77 \%^{\mathrm{a}}$ & $77 \%^{\mathrm{a}}$ & $76 \%^{\mathrm{a}}$ & $74 \%^{\mathrm{a}}$ & $75 \%^{\mathrm{a}}$ & $71 \%^{\mathrm{a}}$ & $<61 \%$ or $>87 \%{ }^{\mathrm{a}}$ \\
\hline Leydig & $\begin{array}{c}\text { Other nonreproductive cells } \\
\text { ITUC }\end{array}$ & $\begin{array}{c}11 \%(5.8 / 20) \\
13 \%^{\mathrm{a}}\end{array}$ & $\begin{array}{c}7.1 \%(2.5 / 12) \\
8.2 \%^{\mathrm{a}}\end{array}$ & $\begin{array}{c}6.6 \%(2.6 / 15) \\
8.5 \%^{\mathrm{a}}\end{array}$ & $\begin{array}{c}6.2 \%(2.2 / 11) \\
8.5 \%^{\mathrm{a}}\end{array}$ & $\begin{array}{l}5.9 \%(0.4 / 11) \\
5.7 \%{ }^{\mathrm{a}, \mathrm{b}}\end{array}$ & $\begin{array}{c}3.5 \%(0.9 / 10) \\
5.0 \%{ }^{\mathrm{a}, \mathrm{b}}\end{array}$ & $<5.7 \%$ or $>28 \%^{\mathrm{a}}$ \\
\hline Sertoli & $\begin{array}{l}\text { Other nonreproductive cells } \\
\qquad \mathrm{VC}+\mathrm{ABC}\end{array}$ & $\begin{array}{c}14 \%(5.5 / 20) \\
58 \% \%^{\mathrm{a}}\end{array}$ & $\begin{array}{c}13 \%(7.6 / 20) \\
65 \%^{\mathrm{a}}\end{array}$ & $\begin{array}{c}16 \%(8.6 / 21) \\
68 \%^{\mathrm{a}}\end{array}$ & $\begin{array}{c}15 \%(5.1 / 22) \\
64 \%^{\mathrm{a}}\end{array}$ & $\begin{array}{c}14 \%(10 / 25) \\
68 \%^{\mathrm{a}}\end{array}$ & $\begin{array}{c}10 \%(6 / 19) \\
40 \%^{\mathrm{a}}\end{array}$ & $<26 \%$ or $>85 \%{ }^{\mathrm{a}}$ \\
\hline VC & $\begin{array}{l}\text { Other nonreproductive cells } \\
\text { ABC }\end{array}$ & $\begin{array}{c}3.5 \%(1.6 / 14) \\
59 \% \%^{\mathrm{a}}\end{array}$ & $\begin{array}{c}1.5 \%(0.0 / 5.7) \\
31 \%^{\mathrm{a}}\end{array}$ & $\begin{array}{c}2.2 \%(0.6 / 11) \\
42 \%^{\mathrm{a}}\end{array}$ & $\begin{array}{c}3.0 \%(0.8 / 7.6) \\
47 \%^{\mathrm{a}}\end{array}$ & $\begin{array}{c}2.4 \%(0.6 / 8.7) \\
41 \%^{\mathrm{a}}\end{array}$ & $\begin{array}{c}4.6 \%(0.6 / 13) \\
27 \%^{\mathrm{a}}\end{array}$ & $<24 \%$ or $>87 \%^{\mathrm{a}}$ \\
\hline $\mathrm{ABC}$ & Other nonreproductive cells & $3.2 \%(0.3 / 12)$ & $2.9 \%(0.8 / 14)$ & $3.6 \%(0.5 / 17)$ & $4.0 \%(0.3 / 15)$ & $4.6 \%(0.5 / 16)$ & $8.4 \%(3.3 / 26)$ & \\
\hline
\end{tabular}

${ }^{a}$ Mean of the inverse logit of frequencies of these cells within given groups of cell types.

${ }^{\mathrm{b}}$ A statistically significant difference in relative cell frequency compared with controls.

${ }^{\mathrm{c}}$ Significance based on nonparametric trend test (Jonckheere-Terpstra).

$\mathrm{VC}=$ vacuolated cells; $\mathrm{ABC}=$ apoptotic body cells; ITUC $=$ interstitial tissue or unknown cells 


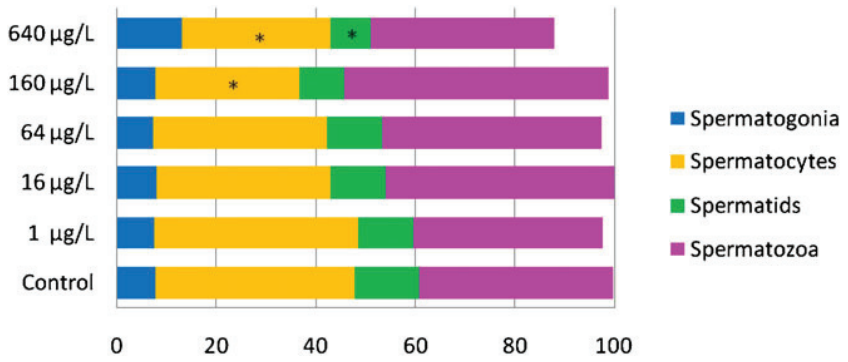

Fig. 3. Percent median cell frequency for male gonad cell types from fathead minnow exposed to bisphenol A (BPA) for $164 \mathrm{~d}$. Asterisks (*) indicate a significant difference in the relative frequency of that cell type within the group of equally and less mature cell types compared with controls.

$(p>0.5)$, the frequency of Leydig cells and ITUC within the non-germ cells $(p=0.28)$, the frequency of Sertoli cells within the group of Sertoli cells, $\mathrm{VC}$, and $\mathrm{ABC}(p=0.22)$, and the frequency of VC within the group of $\mathrm{VC}$ and $\mathrm{ABC}(p=0.0082)$. There was a statistically significant difference between the control and 160 and $640 \mu \mathrm{g} / \mathrm{L}$ concentration groups for the logits of the frequency of Leydig cells within the group of Leydig cells and ITUC ( $p=0.000083$ and 0.000037 , respectively). The Leydig cell frequency was lower at BPA concentrations greater than $160 \mu \mathrm{g} / \mathrm{L}$ than in the control.

For ovaries, a simultaneous statistically significant decrease in the relative frequency of early vitellogenic cells within the group of equally and less mature cell types was observed at $640 \mu \mathrm{g} / \mathrm{L}$ compared with the control group (Table 4, Fig. 4). Variable-wise but not simultaneously significant differences were observed between the control and $640 \mu \mathrm{g} / \mathrm{L}$ exposure groups for the logits of the relative frequency of cortical alveolar cells within its group of equally and less mature cell types ( $p=0.0019$ ). No significant effects were observed on the relative frequency of atretic, mature, and late vitellogenic cell types $(p=0.25,0.79$, and 0.14 , respectively).

\section{DISCUSSION}

In the present study, population-relevant endpoints were assessed in combination with diagnostic-type biomarker endpoints in fathead minnows exposed to BPA for $164 \mathrm{~d}$. The present study design was developed in conjunction with the UK Environment Agency, and its purpose was to clarify the results of a previous study $[13,15]$ in which gonadal histopathological endpoints were evaluated but deemed of poor and unreliable quality [14]. The previous study [13,15] described a multigenerational fathead minnow exposure to BPA that examined both population-relevant and biomarker endpoints over three generations. Fish survival, standard growth, fecundity and hatchability, as well as gonad growth, plasma VTG, and histology of the gonads were assessed. For male fish, gonad histopathology included a scoring of the various testicular cell types to assess impacts on spermatogenesis. Measurements were made on the relative proportions of each of four gonadal cell stages (i.e., spermatogonia, spermatocytes, spermatids, and spermatozoa).

Although the population-relevant study endpoints that concerned survival, growth, reproduction, and VTG measurements $[13,15]$ were considered to be valid, on review of the histologic procedures it was noted that the study was not designed to assess impacts on gonadal cell types [14]. The evaluation of gonadal cell types was added to the test design after the study plan had been implemented, and thus this assessment was not integrated into the original study development. An insufficient number of fish were sampled, tissue dissection and preparation for cell counting was not optimized, and the number of cells counted was inadequate. In addition, the statistical methods used to compare the proportions of cell types between control and treated fish were not appropriate because the relative numbers of each cell type were not handled independently [14].

To address the shortcomings of the Sohoni et al. [13] gonadal cell evaluation, a series of experiments were carried out on

Table 4. Percentage of median cell frequency (and upper and lower 10th percentile) for the female reproductive cell types evaluated and the mean of the inverse logit of frequencies of these cells within given groups of cell types ${ }^{\mathrm{a}}$

\begin{tabular}{|c|c|c|c|c|c|c|c|c|}
\hline $\begin{array}{l}\text { Nomi } \\
\text { treatme }\end{array}$ & $\begin{array}{l}\text { nal BPA } \\
\text { nts }(\mu g / L)\end{array}$ & Control & 1 & 16 & 64 & 160 & 640 & $\begin{array}{c}\text { Significantly } \\
\text { different from } \\
\text { control if... }\end{array}$ \\
\hline Atretic oocytes & All other oocytes & $\begin{array}{c}1.8 \%(0.3 / 9.1) \\
2.3 \%^{\mathrm{a}}\end{array}$ & $\begin{array}{c}2.2 \%(0.4 / 12) \\
2.0 \%^{\mathrm{a}}\end{array}$ & $\begin{array}{c}1.6 \%(0.3 / 12) \\
1.7 \%^{\mathrm{a}}\end{array}$ & $\begin{array}{c}1.4 \%(0.0 / 8.6) \\
1.5 \%^{\mathrm{a}}\end{array}$ & $\begin{array}{c}0.7 \%(0.0 / 7.0) \\
1.0 \%^{\mathrm{a}}\end{array}$ & $\begin{array}{c}2.8 \%(0.2 / 11) \\
2.3 \%^{\mathrm{a}}\end{array}$ & $<0.6 \%^{\mathrm{a}}$ \\
\hline Mature oocytes & $\begin{array}{c}\text { All other oocytes } \\
\text { Less mature oocytes }\end{array}$ & $\begin{array}{c}0.0 \%(0.0 / 0.3) \\
0.4 \%^{\mathrm{a}}\end{array}$ & $\begin{array}{c}0.0 \%(0.0 / 0.0) \\
0.4 \%^{\mathrm{a}}\end{array}$ & $\begin{array}{c}0.0 \%(0.0 / 1.4) \\
0.4 \%^{\mathrm{a}}\end{array}$ & $\begin{array}{c}0.0 \%(0.0 / 0.5) \\
0.3 \%^{\mathrm{a}}\end{array}$ & $\begin{array}{c}0.0 \%(0.0 / 1.0) \\
0.4 \%^{\mathrm{a}}\end{array}$ & $\begin{array}{c}0.0 \%(0.0 / 1.9) \\
0.4 \%^{\mathrm{a}}\end{array}$ & $<0.2 \%^{\mathrm{a}}$ \\
\hline $\begin{array}{l}\text { Late vitellogenic } \\
\text { oocytes }\end{array}$ & $\begin{array}{c}\text { All other oocytes } \\
\text { Less mature oocytes }\end{array}$ & $\begin{array}{c}8.6 \%(1.3 / 16) \\
6.5 \%^{\mathrm{a}}\end{array}$ & $\begin{array}{c}8.0 \%(0.5 / 18) \\
6.5 \%^{\mathrm{a}}\end{array}$ & $\begin{array}{c}8.0 \%(0.4 / 19) \\
4.0 \%^{\mathrm{a}}\end{array}$ & $\begin{array}{c}12 \%(0.9 / 20) \\
7.2 \%^{\mathrm{a}}\end{array}$ & $\begin{array}{c}10 \%(1.0 / 20) \\
6.8 \%^{\mathrm{a}}\end{array}$ & $\begin{array}{c}5.0 \%(0.6 / 15) \\
3.9 \%^{\mathrm{a}}\end{array}$ & $<1.7 \%^{\mathrm{a}}$ \\
\hline $\begin{array}{l}\text { Early vitellogenic } \\
\text { oocytes }\end{array}$ & $\begin{array}{c}\text { All other oocytes } \\
\text { Less mature oocytes }\end{array}$ & $\begin{array}{c}7.5 \%(4.6 / 10) \\
8.0 \%^{\mathrm{a}}\end{array}$ & $\begin{array}{c}7.2 \%(2.7 / 11) \\
6.2 \%^{\mathrm{a}}\end{array}$ & $\begin{array}{c}8.2 \%(4.4 / 15) \\
9.3 \%^{\mathrm{a}}\end{array}$ & $\begin{array}{c}7.4 \%(3.4 / 11) \\
6.8 \%^{\mathrm{a}}\end{array}$ & $\begin{array}{c}6.4 \%(2.7 / 11) \\
6.0 \%^{\mathrm{a}}\end{array}$ & $\begin{array}{c}5.1 \%(1.8 / 8.9) \\
4.2 \%\end{array}$ & $<3.8 \%^{\mathrm{a}}$ \\
\hline $\begin{array}{l}\text { Cortical alveolar } \\
\text { oocytes }\end{array}$ & $\begin{array}{c}\text { All other oocytes } \\
\text { Less mature oocytes }\end{array}$ & $\begin{array}{c}21 \%(18 / 31) \\
26 \%^{\mathrm{a}}\end{array}$ & $\begin{array}{c}23 \%(16 / 29) \\
27 \%^{\mathrm{a}}\end{array}$ & $\begin{array}{c}23 \%(16 / 29) \\
25 \%^{\mathrm{a}}\end{array}$ & $\begin{array}{c}22 \%(18 / 27) \\
26 \% \%^{\mathrm{a}}\end{array}$ & $\begin{array}{c}21 \%(14 / 28) \\
23 \%^{\mathrm{a}}\end{array}$ & $\begin{array}{c}17 \%(12 / 28) \\
21 \%^{\mathrm{a}}\end{array}$ & $<19 \%^{\mathrm{a}}$ \\
\hline $\begin{array}{c}\text { Perinucleolar } \\
\text { oocytes }\end{array}$ & All other oocytes & $60 \%(40 / 67)$ & $58 \%(43 / 69)$ & $53 \%(38 / 71)$ & $58 \%(41 / 66)$ & $61 \%(42 / 73)$ & $64 \%(46 / 78)$ & \\
\hline
\end{tabular}

${ }^{a}$ Mean of the inverse logit of frequencies of these cells within given groups of cell types

${ }^{\mathrm{b}}$ Statistically significant difference in relative cell frequency compared with controls.

${ }^{\mathrm{c}}$ Significance based on nonparametric trend test (Jonckheere-Terpstra).

$\mathrm{BPA}=$ bisphenol A. 


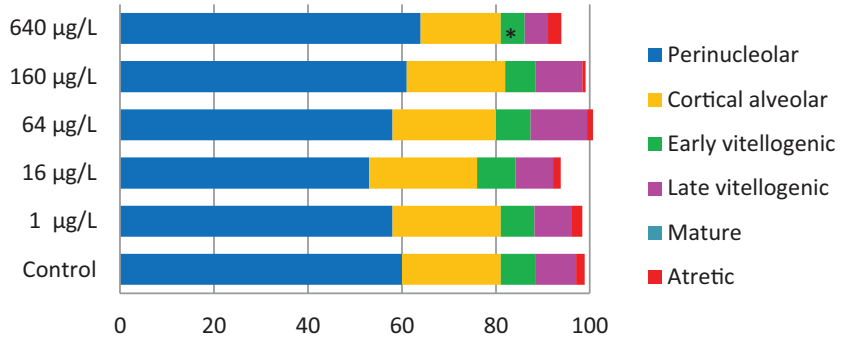

Fig. 4. Percent median cell frequency for female gonad cell types from fathead minnow exposed to bisphenol A (BPA) for $164 \mathrm{~d}$. Asterisks (*) indicate a significant difference in the relative frequency of that cell type within the group of equally and less mature cell types compared with controls.

fathead minnows to investigate specifically the possible gonadal effects from exposure to BPA. The initial phase of the work consisted of the development and optimization of methods to visualize and differentially quantify male and female gonadal cell types [16]. This work was followed by a 42-d range-finding study that demonstrated the utility of the histological methods and evaluated the natural variability of the distribution of gonadal cell types to develop a statistically robust experimental design. The definitive 164-d study reported here was designed using the findings of Wolf et al. [16], and the results of additional testing to ensure the statistical robustness and appropriate assessment of both population-relevant endpoints and more targeted biomarker and cellular responses.

The most prominent microscopic effect of BPA was the presence of proteinaceous intravascular (with or without interstitial) fluid in the gonads (Fig. 2). Findings of intravascular or extravascular proteinaceous fluid in the testis and ovary are not without precedence. In previous studies in which zebrafish were exposed to exogenous estrogenic substances, this type of change was attributed to increased hepatic production and circulatory release of VTG, the presence of which was confirmed immunohistochemically [24,25]. In the present study, the incidence and severity of this finding were generally higher in male than in female fish. This result is consistent with comparably higher measured levels of plasma VTG in the BPA-exposed male fish (Fig. 1). This sex-based difference is most likely attributable to the comparative lack of VTG utilization/consumption in male fish, whereas VTG is incorporated into yolk production in females. In males, therefore, VTG accumulates intravascularly because the threshold for elimination is exceeded [26].

Fathead minnow are fractional spawners; thus, the various gametogenic cell types are typically represented in the gonads concurrently [27]. This makes them a particularly good model to employ in a quantitative assessment of subtle treatmentrelated effects on the developmental progression of gametogenesis. In males, spermatogenesis proceeds according to the following sequence: spermatogonia $\rightarrow$ spermatocytes $\rightarrow$ spermatids $\rightarrow$ spermatozoa [27-29]. Similarly, oogenesis proceeds through the following sequence of follicular maturation phases: perinucleolar $\rightarrow$ cortical alveolar $\rightarrow$ early vitellogenic $\rightarrow$ late vitellogenic $\rightarrow$ mature/spawning. Follicular atresia can occur throughout the cycle, but it most commonly becomes evident in the later stages of follicular development, as a consequence of physiological stimuli or environmental stress $[27,30]$. Although few studies have employed histomorphometric procedures to both categorize and quantify different gonadal cell types, estrogenic compounds have been shown to result in a delay or regression in gametogenic development that causes earlier gametogenic cells to predominate [11,31,32]. A shift in the relative quantity of gonadal cells at a particular stage in relation to the gametogenic progression in control fish could signal an impact on reproductive physiology, although population-relevant links to reproductive success remain unsubstantiated for low concentrations of estrogens or estrogenic-like compounds in the aquatic environment.

In the present study, only the highest concentrations of BPA were associated with marginal relative shifts to less mature gametogenic cell types in both males and females. These marginal shifts in maturity were not associated with any statistically significant effects on reproductive performance. Concerning the relative frequencies of several non-germ cell types, the sole significant finding was a decreased ratio of Leydig cells relative to the ITUC at 160 and $640 \mu \mathrm{g} / \mathrm{L}$ concentrations. In most fish species, Leydig cells are typically present in low numbers and are scattered widely throughout the testis. Few studies have quantitatively examined the potential effects of compounds on the Leydig cells of fish or other animals. Similar to the marginal relative shift in age of gametogenic cell types, the decreased ratio of Leydig cells relative to ITUC was not associated with any statistically significant effects on reproductive performance in the present study.

Although measurements such as VTG have not been causally linked to adverse effects, such tools are useful for monitoring exposure to anthropogenic compounds [33-35]. However, because analytical techniques for quantifying VTG have not been standardized, directly comparing baseline concentrations of VTG across studies is difficult. The OECD and others [36,37] have reported considerable variation between VTG levels in control fish among different studies, even when similar assays or the same species were used. However, the control male and female VTG concentrations measured in the present study (Fig. 1) were similar to those reported by Sohoni et al. [13], with plasma VTG in the low $\mathrm{ng} / \mathrm{ml}$ range in males and low $\mu \mathrm{g} / \mathrm{ml}$ range in females. In addition, in both the original study [13] and the present study, the statistically derived no observed effect concentration for VTG induction was $16 \mu \mathrm{g} / \mathrm{L}$.

However, whereas biomarker endpoints may provide additional information on the mode of action, and thus potentially expand diagnostic capabilities, for example, of an endocrine activity-focused bioassay, they did not in this case predict population-relevant adverse effects. No effects were seen on male and female growth, gonad weight, gonadosomatic index, or reproduction variables at the tested concentration range. Although gonad cell type frequencies were significantly different in males, with a decrease in spermatocytes compared with the less mature cell types (at concentrations $\geq 160 \mu \mathrm{g} / \mathrm{L}$ ), the number of spermatozoa (the subsequent maturation phase) was unaffected, and the observation did not result in a decrease in the fertility or hatchability of the eggs. The same can be said of the sole treatment-related effect in females, in which a decrease in early vitellogenic cells as compared with less mature cells was observed at $640 \mu \mathrm{g} / \mathrm{L}$, and for the increased VTG in males and females that occurred at more than $64 \mu \mathrm{g} / \mathrm{L}$ in both sexes. None of these observations resulted in population-relevant effects on the reproductive parameters measured in the present study. Notable findings were the reduction in male survival at $640 \mu \mathrm{g} / \mathrm{L}$ and the renal lesions in male fish of the 160 and $640 \mu \mathrm{g} / \mathrm{L}$ concentration groups. Although determination of the cause of death in these fish would be difficult, possibly the high circulating levels of VTG and associated renal damage contributed to the higher mortality observed in the high concentration fish. Previous studies have documented the association 
between similar types of renal lesions and elevated VTG in male fish [38,39].

Bosker et al. [40] cautioned that using biomarkers to quantitatively predict population-level effects could result in high uncertainty. Although biomarkers may be an indication of exposure, the link to functional impairment and the mechanism of toxicity are often not established $[41,42]$. That caveat would certainly apply to the results of the present study, as observations on the biomarker endpoints did not correlate with effects on reproduction. Therefore, a high degree of uncertainty exists for other BPA studies that measure only biomarker endpoints and not their population relevance. For example, although the study by Lahnsteiner et al. [10] was used in a screening-level risk assessment [43], this same study was not used in the comprehensive EU risk assessment because it was not deemed to be of sufficient relevance or reliability for that purpose [14], given that the reported effects of BPA on gamete quality in wild-caught brown trout were not evaluated against any measures of reproductive success or population relevant endpoints. Given the lack of correlation in the present study between biomarkers and reproductive effects, in combination with the methodological limitation of the Lahnsteiner et al. study (e.g., lack of replication, lack of confirmation of reproductive status of the wild-caught fish, low numbers of fish, no analytical confirmation of concentration), the use of the Lahnsteiner et al. study to predict population level effects of BPA would be highly questionable.

An important aspect in the development and performance of the present study was the use of appropriate statistical procedures. Increasing the number of variables reduces the power $(1-\beta)$ or likelihood of detecting a treatment-related effect for each specific variable. The MSD of a given variable depends not only on the observed variance but also on the number of replicates and the significance level that were used in the statistical tests. If the experimental significance level $(\alpha)$ must be split over many variables, then the MSD increases for each variable, and the power to detect an effect decreases. Grouping variables in a scientifically rational way, and then splitting the significance level, first among the groups and subsequently among the variables within the group, increases the probability of detecting a true effect on the most relevant variables. By grouping similar variables before splitting the significance level, a lower MSD and higher level of detection was obtained in the present study, when compared with splitting the significance level equally across all variables, regardless of whether they are similar. Statistical power to detect an effect can also be increased by combining the testing of the individual variables in a multivariate analysis, as we have done for the lesion scores with a redundancy analysis. Such an analysis allows one to observe the presence of an effect on the combined set of variables and shows which variables contribute most to the variance caused by the treatment, in this case the BPA concentration.

In terms of study design, multigenerational studies may be more sensitive than partial or full-life cycle tests at identifying effects from chemicals that interact with the endocrine systems of fish [44]. However, this suggestion pertains primarily to compounds that bioaccumulate or are relatively insoluble in water because a long time is required for the concentration of the chemical to build up and be transferred through the mother to the offspring. Bisphenol A is moderately water soluble, readily biodegradable, and is known to be metabolized to BPA-glucuronide and BPA-sulfate conjugates in teleosts $[45,46]$. With such a compound, the current partial life-cycle design is appropriate to evaluate population-level impacts of survival, growth, and reproduction on fathead minnows exposed to BPA.

\section{CONCLUSION}

Studies that encompass the majority of the life cycle, or those maintained through multiple generations, have the ability to detect ecologically relevant effects of chemicals in organisms. In this 164-d study, with the exception of reduced survival in males at $640 \mu \mathrm{g} / \mathrm{L}$, no statistically significant effects were seen at any treatment level in males or females with respect to survival, growth, fecundity, hatchability, and gonadosomatic index. Statistically significant histopathological findings at 160 and $640 \mu \mathrm{g} / \mathrm{L}$ in males and $640 \mu \mathrm{g} / \mathrm{L}$ in females were based on the occurrence of intravascular proteinaceous fluid in the testes of males and intravascular and interstitial proteinaceous fluid in the ovaries of females, and a marginal relative shift to less mature gametogenic cell types in both males and females at those concentrations. These results stand in contrast to results reported in a similar study by Sohoni et al. [13], in which a shift to less mature spermatogenic cell types was observed at concentrations as low as or lower than those reported for other endpoints, including VTG. Because sampling and examination of gonadal tissues in the Sohoni et al. study were not optimized for evaluating the relative frequency of gonadal cells, the greater objectivity and comprehensiveness of the study presented here, when compared with Sohoni et al., allowed for a robust assessment of the histological endpoints in relation to more common apical and environmentally relevant effects. In the present study, the marginal shifts in gametogenic cell maturation and the presence of histopathological findings were not associated with any statistically significant effects on population-relevant reproductive performance endpoints (growth, fecundity, and hatchability) at any concentration. Thus, the ecologically relevant no observed effect concentration for the present study was $160 \mu \mathrm{g} / \mathrm{L}$ based on male survival.

Acknowledgement-The authors thank their colleagues G.Klecka and U. Friederich from Dow Chemical for their scientific and technical support, as well as L. Fisher and L. Hall from Toxicology Regulatory Services for their attention to quality assurance detail throughout the study. We also thank the anonymous reviewers for their insightful review of this manuscript. ABC Laboratories is an Association for Assessment and Accreditation of Laboratory Animal Care International-accredited facility. The authors are either employed by companies that produce and sell bisphenol A (BPA) as well as certain other products that contain BPA or are independent contractors who have provided consulting or testing services to both government and industry. This project was funded by the Polycarbonate/BPA Global Group, Washington, DC.

\section{REFERENCES}

1. Klecka GM, Gonsior SJ, West RJ, Goodwin PA, Markham DA. 2001. Biodegradation of bisphenol A in aquatic environments: River die-away. Environ Toxicol Chem 20:2725-2735.

2. West RJ, Goodwin PA, Klecka GM. 2001. Assessment of the ready biodegradability of bisphenol A. Bull Environ Contam Toxicol 67:106-112.

3. Staples CA, Dorn PB, Klecka GM, O’Block ST, Harris LR. 1998. A review of the environmental fate, effects, and exposures of bisphenol A. Chemosphere 36:2149-2173.

4. Cousins IT, Staples CA, Klecka GM, Mackay D. 2002. A multimedia assessment of the environmental fate of bisphenol A. Hum Ecol Risk Assess 8:1107-1135.

5. Klecka GM, Staples CA, Clark KE, van der Hoeven N, Thomas DE, Hentges SG. 2009. Exposure analysis of bisphenol A in surface water systems in North America and Europe. Environ Sci Technol 43:61456150.

6. Smeets JMW, van Holsteijn I, Giesy JP, Seinen W, van der Berg M. 1999. Estrogenic potencies of several environmental pollutants, as determined 
by vitellogenin induction in carp hepatocyte assay. Toxicol Sci 50:206213.

7. Lindholst C, Pedersen KL, Pedersen SN. 2000. Estrogenic response of bisphenol A in rainbow trout (Oncorhynchus mykiss). Aquat Toxicol 48:87-94.

8. Vos JG, Dybing E, Greim HA, Ladefoged O, Lambre C, Tarazona JV, Brandt I, Vethaak AD. 2000. Health effects of endocrine-disrupting chemicals on wildlife, with special reference to the European situation. Crit Rev Toxicol 30:71-133.

9. Ankley GT, Giesy JP. 1998. Endocrine disruptors in wildlife: A weight of evidence perspective. In Kendall RJ, Dickerson RL, Giesy JP, Suk WP, eds, Principles and Processes for Assessing Endocrine Disruption in Wildlife. SETAC, Pensacola, FL, USA, pp 349-368.

10. Lahnsteiner F, Berger B, Kletzl M, Weismann T. 2005. Effect of bisphenol A on maturation and quality of semen and eggs in the brown trout, Salmo trutta f. fario. Aquat Toxicol 75:213-224.

11. Van der Ven LTM, Holbech H, Fenske M, Van den Brandhof EJ, GielisProper FK, Wester PW. 2003. Vitellogenin expression in zebrafish Danio rerio: Evaluation by histochemistry, immunohistochemistry, and in situ mRNA hybridization. Aquat Toxicol 65:1-11.

12. Hutchinson TH, Ankley GT, Segner H, Tyler CR. 2006. Screening and testing for endocrine disruption in fish-biomarkers as "signposts," not "traffic lights," in risk assessment. Environ Health Perspect 114: 106-114.

13. Sohoni P, Tyler CR, Hurd K, Caunter J, Hetheridge M, Williams T, Woods C, Evans M, Toy R, Gargas M, Sumpter JP. 2001. Reproductive effects of long-term exposure to Bisphenol A in the fathead minnow (Pimephales promelas). Environ Sci Technol 35:2917-2925.

14. European Commission. 2010. European Union Risk Assessment Report: Isopropylidenediphenol (Bisphenol-A). CAS: 80-05-7, EINECS 594 201-245-8. European Commission Joint Research Centre, Ispra, Italy

15. Staples CA, Hall AT, Friederich U, Caspers N, Klecka GM. 2011. Early life-stage and multigeneration toxicity study with bisphenol A and fathead minnows (Pimephales promelas). Ecotoxicol Environ Saf 74:1548-1557.

16. Wolf JC, Dietrich DR, Friederich U, Caunter J, Brown AR. 2004. Qualitative and quantitative histomorphologic assessment of fathead minnow Pimephales promelas gonads as an endpoint for evaluating endocrine-active compounds: A pilot methodology study. Toxicol Path 32:600-612.

17. Organisation for Economic Co-operation and Development. 1992. Report of the OECD Workshop on the Extrapolation of Laboratory Aquatic Toxicity Data to the Real Environment. OECD Environment Monograph 59. Paris, France.

18. Zeeman MG, Gilford J. 1993. Ecological hazard evaluation and risk assessment under EPA's Toxic Substances Control Act: An Introduction. In Landis WG, Hughes JS, Lewis MA, eds, Environmental Toxicology and Risk Assessment. STP 1179. American Society for Testing and Materials, West Conshohocken, PA, pp 7-21.

19. U.S. Environmental Protection Agency. 1986. Hazard Evaluation Division Standard Evaluation Procedure: Fish Life-Cycle Toxicity Tests, EPA 540/9-86/Washington DC.

20. U.S. Environmental Protection Agency. 1989. Pesticide Programs; Good Laboratory Practice Standards; Final Rule (40 CFR, Part 160). Fed Reg 54:34052.

21. U.S. Environmental Protection Agency. 1989. Toxic Substances Control Act; Good Laboratory Practice Standards; Final Rule (40 CFR, Part 792). Fed Reg, 54:158 34043-34050.

22. Organisation for Economic Co-operation and Development. 2000. Guidance Document on Aquatic Toxicity Testing of Difficult Substances and Mixtures. OECD Environmental Health and Safety Publications Series on Testing and Assessment 23. Paris, France.

23. ter Braak CJF, Prentice IC, 1988. A theory of gradient analysis. Adv Ecol Res 18:271-317.

24. Wester PW, van der Ven LTM, vanden Brandhhof EJ, Vos JH, 2003. Identification of endocrine disruptive effects in the aquatic environment: A partial life cycle assay in zebrafish. RIVM Report 640920001/2003, Bilthoven, The Netherlands, pp 30-49.

25. Van den Belt K, Wester PW, van der Ven LT, Verheyen R, Witters H. 2002. Effects of ethynylestradiol on the reproductive physiology in zebrafish (Danio rerio): Time dependency and reversibility. Environ Toxicol Chem 21:767-775.

26. Folmar LC, Gardner GR, Schreibman MP, Magliulo-Cepriano L, Mills LJ, Zaroogian G, Gutjahr-Gobell R, Haebler R, Horowitz DB, Denslow ND. 2001. Vitellogenin-induced pathology in male summer flounder (Paralichthys dentatus). Aquat Toxicol 51:431-441.

27. U.S. Environmental Protection Agency. 2002. A short-term test method for assessing the reproductive toxicity of endocrine-disrupting chemicals using the fathead minnow (Pimephales promelas). EPA 600/R-01-067. Washington, DC, pp 141, 144.

28. Grier HJ. 1981. Cellular organization of the testis and spermatogenesis in fishes. Am Zool 21:345-357.

29. Pudney J. 1995. Spermatogenesis in nonmammalian vertebrates. Microsc Res Tech 32:459-497.

30. Tyler CR, Sumpter JP. 1996. Oocyte growth and development in teleosts. Rev Fish Biol Fish 6:287-318.

31. Salierno JD, Kane AS. 2009. 17 $\alpha$-ethinylestradiol alters reproductive behaviors, circulating hormones, and sexual morphology in male fathead minnows (Pimephales promelas). Environ Toxicol Chem 28:953-961.

32. Miles-Richardson SR, Kramer VJ, Fitzgerald SD, Render JA, Yamini B, Barbee SJ, Giesy JP. 1999. Effects of waterborne exposure of $17 \beta$ estradiol on secondary sex characteristics and gonads of fathead minnows (Pimephales promelas). Aquat Toxicol 47:129-145.

33. Sumpter JP, Jobling S. 1995. Vitellogenesis as a biomarker for estrogenic contamination of the aquatic environment. Environ Health Perspect 103(Suppl 7):173-178.

34. Tyler CR, van der Eerden B, Jobling S, Panter G, Sumpter JP. 1996 Measurement of vitellogenin, a biomarker for exposure to oestrogenic chemicals, in a wide variety of cyprinid fish. J Comp Physiol B 166:418426.

35. Miller DH, Jensen KM, Villeneuve DL, Kahl MD, Makynen EA, Durhan EJ, Ankley GT. 2007. Linkage of biochemical responses to populationlevel effects: A case study with vitellogenin in the fathead minnow (Pimephales promelas). Environ Toxicol Chem 26:521-527.

36. Organisation for Economic Co-operation and Development. 2006. Report of the initial work towards the validation of the 21-day fish screening assay for the detection of endocrine active substances (phase 1B). OECD Environmental Health and Safety Publications Series on Testing and Assessment 61. Paris, France.

37. Wheeler JR, Gimeno S, Crane M, Lopez-Juez E, Morritt D. 2005. Vitellogenin: A review of analytical methods to detect (anti) estrogenic activity in fish. Toxicol Mech Methods 15:293-306.

38. Herman RL, Kincaid HL. 1988. Pathological effects of orally administered estradiol to rainbow trout. Aquaculture 72:165-172.

39. Palace VP, Evans RE, Wautier K, Baron C, Vandenbyllardt L, Vandersteen W, Kidd K. 2002. Induction of vitellogenin and histological effects in wild fathead minnows from a lake experimentally treated with the synthetic estrogen ethynylestradiol. Water Qual Res J Canada 37:637-650.

40. Bosker T, Munkittrick KR, MacLatchy DL. 2010. Challenges and opportunities with the use of biomarkers to predict reproductive impairment in fishes exposed to endocrine disrupting substances. Aquat Toxicol 100:9-16.

41. Hyne RV, Maher WA. 2003. Invertebrate biomarkers: Links to toxicosis that predict population decline. Ecotoxicol Environ Saf 54:366-374.

42. Forbes VE, Palmquist A, Bach L. 2006. The use and misuse of biomarkers in ecotoxicology. Environ Toxicol Chem 25:272-280.

43. Environment Canada/Health Canada. 2008. Screening assessment for the challenge: Phenol, 4,4'-(1-methylethylidene)bis- (bisphenol A) Ottawa, Canada.

44. Organisation for Economic Co-operation and Development. 2008 Detailed review paper on fish life-cycle tests. No. 95. OECD Environmental Health and Safety Publications Series on Testing and Assessment 95. Paris, France.

45. Lindholst C, Pedersen SN, Bjerregaard P. 2001. Uptake, metabolism, and excretion of bisphenol $\mathrm{A}$ in the rainbow trout (Oncorhynchus mykiss). Aquat Toxicol 55:75-84

46. Lindholst C, Wynne PM, Marriott P, Pedersen SN, Bjerregaard P. 2003. Metabolism of bisphenol A in zebrafish (Danio rerio) and rainbow trout (Oncorhynchus mykiss) in relation to estrogenic response. Comp Biochem Physiol Part C Toxicol Pharmacol 135:169-177. 